\title{
In vitro propagation of Withania somnifera (L.) Dunal. from shoot apex explants
}

\author{
Archana Rani*, M. Kumar and Sanjeev Kumar ${ }^{1}$ \\ Department of Agricultural Biotechnology and Molecular Biology, (FBS \& H), Rajendra Agricultural University \\ Pusa-848125 (Bihar), INDIA \\ ${ }^{1}$ Department of Plant Pathology, College of Agriculture, Jawaharlal Nehru Krishi Vishwa Vidyalaya \\ Jabalpur- 482004 (M.P.), INDIA \\ *Corresponding author. E-mail: archanarani22oct@gmail.com
}

Received: March 4, 2014; Revised received: March 22, 2014; Accepted: April 24, 2014

\begin{abstract}
In vitro rapid micropropagation of Withania somnifera; has been achieved using shoot apex explants, when cultured on MS medium with different auxins: Indole Butyric Acid (IBA) 0.5-4 mg/l, Indole Acetic Acid (IAA) 2 $\mathrm{mg} / \mathrm{l}$ and Naphthalene Acetic Acid (NAA) 0.5-3 mg/l and cytokinin: Benzyl Amino Purine (BAP) 0.5-4 mg/l. NAA and BAP stimulated direct as well as callus mediated multiple shoot. IBA alone and in combination with IAA stimulated rhizogenesis, while IBA with NAA proliferated callus-mediated rhizogenesis. The rooted plantlets through sequential hardening process could be established in the field.
\end{abstract}

Keywords: Micropropagation, Shoot apex explant, Rhizogneesis, Withania somnifera

\section{INTRODUCTION}

Withania somnifera (L.) Dunal. is an erect, evergreen, perennial shrub. It is a potential medicinal plant that has been used medicinally in the treatment of tuberculosis, rheumatism, inflammatory conditions, cardiac diseases, and it is used as a general tonic, anti-stress drug and as an antitumor, antibiotic, anticonvulsant besides being an ingredient of several ayurvedic preparations (Mishra et al., 2000; Kumar et al., 2011 and Patel and Krishnamurthy, 2013). It is also useful as abortificient, amoebicide, anodyne, bactericide, contraceptive, and spasmolytic (Asthana and Raina, 1989). With the increasing demand for the roots of $W$. somnifera in larger quantities, it is cultivated almost as a commercial crop in India. The production of $W$. somnifera roots through conventional methods of cultivation (seed) is less than the requirement due to numerous reasons viz. poor yield, takes long time, poor viability of seeds, susceptibility of the seeds and seedlings to fungal infections like seedling mortality and blight, leaf blight, seed rotting etc (Misra et al., 1997). This medicinally significant plant species has been depleted from its natural habitat and is now included in the list of endangered species (Kanungo and Sahoo, 2011; Patel and Krishnamurthy 2013) by the International Union for Conservation of Nature and Natural Resources (Kavidra et al., 2000; Supe et al., 2006). The rapid multiplication of $W$. somnifera by tissue culture techniques can help to solve these problems and the benefits are extensive in the agricultural world. The plant tissue culture is desirable in order to satisfy production demands, which has been developed for the mass propagation of medicinal plants (Thomas and Shankar, 2009), the conservation of particular and endangered species (Nagesh, 2008; Offord and Tyler, 2009; Kumar et al., 2011). The present study was undertaken to establish an efficient protocol for rapid plant regeneration from shoot apex explants of $W$. somnifera (L.) Dunal.

\section{MATERIALS AND METHODS}

The shoots of about $1.5-2 \mathrm{~cm}$ long were collected from apex of 2 years old genotype WA-20 of W. somnifera for standardization of regeneration protocol in Department of Agricultural Biotechnology and Molecular Biology at Rajendra Agricultural University Pusa, Bihar. Collected explants were first washed with running tap water (15 minutes) and then surface sterilized with Tween-20 ( 2 drop/100ml) , 70\% ethanol for 1-1 minutes and were rinsed in distilled water thrice. Then, they were taken to the laminar air flow chamber where treated with $0.1 \% \mathrm{HgCl}_{2}$ for 2 minutes and washed with sterile distilled water. It was then inoculated in the appropriate MS medium, which contained sucrose (3\%), and $\mathrm{pH}$ (5.8). Cutting edge of the explants should make a direct contact with medium. The cultures were incubated at $24 \pm 2^{\circ} \mathrm{C}$ under 2000 lux light intensity provided by white fluorescent lamp for 16 hours photoperiod. The basal MS medium was used with derived supplementation of 
phytoregulators for callusing and induction of shoots and roots. The MS basal media were supplemented with different auxins: Indole Butyric Acid (IBA) 0.5-4 $\mathrm{mg} / \mathrm{l}$, Indole Acetic Acid (IAA) $2 \mathrm{mg} / \mathrm{l}$ and Naphthalene Acetic Acid (NAA) 0.5-3 mg/l and cytokinin: Benzyl Amino Purine (BAP) 0.5-4 mg/l. The rooted shoots were removed from the culture tube and washed with sterile water to remove traces of agar sticking on the roots and dipped in $0.2 \%$ (W/V) bavistin solution for $20 \mathrm{~min}$. Shoots were transferred to plastic pots filled with sterile soil and kept in green house. Initially, the pots were covered with polybags. After 20 days, they were uncovered and shifted gradually from shade to sunlight.

\section{RESULTS AND DISCUSSION}

The present study of in vitro propagation of $W$. somnifera includes multiple shoot formation from shoot tip explants, elongation of regenerated shoots and rooting and hardening of the elongated shoots.

Callus and multiple shoot formation from shoot tip explants: In this process axillary buds were forced to produce multiple shoots with higher concentration of cytokinin in comparison to auxin. Shoot tip explants of $W$. somnifera were inoculated on MS basal media with different concentrations $(0.5,1.0,2.0,3.0,4.0)$ of BAP with $(0.5,1.0,2.0,3.0)$ of NAA for multiple shoot formation. Sprouting of shoot buds from the swollen basal part of the shoot apex explants was noticed after 10 days of incubation in presence of NAA and BAP. All the combinations of NAA with BAP developed multiple shoot buds with varying degree of callus at the base except MS medium $0.5 \mathrm{mg} /$ 1 BAP with $3.0 \mathrm{mg} / \mathrm{l}$ and $2.0 \mathrm{mg} / \mathrm{l} \mathrm{NAA} \mathrm{having}$ tendency to direct shoot regeneration (Plate 1a, b). The amount of callus formation and the number of shoot bud proliferation per explants gradually increased with the increasing concentrations of BAP along with a concomitant suppression of shoot elongation. Similar results were also reported by Ghosh and Banerjee (2003) in Rauvolfia tetraphylla. The best response of shoot differentiation was achieved at $4 \mathrm{mg} / \mathrm{l}$ BAP with $1 \mathrm{mg} / \mathrm{l}$ NAA where about 7.56 shoot buds per explants as well as callus induction could be observed (Table 1).Ojha and Choudhary (2013) reported that stem explants of Stevia rebaudiana cultured on MS media having $0.5 \mathrm{mg} / \mathrm{L}-1 \mathrm{BAP}+0.5 \mathrm{mg} / \mathrm{L}-1 \mathrm{NAA}$ showed 65 $\%$ shoot proliferation while only $14 \%$ callusing found on higher conc. of $2.0 \mathrm{mg} / \mathrm{L}-1 \mathrm{BAP}+2.0 \mathrm{mg} / \mathrm{L}-1$ NAA. Panwar et al. (2011) observed that the callus derived from leaves and stem explants cultured on MS medium containing BAP (2.0 mg 1$)$ with NAA $(0.5$ mg l) was most effective combination for multiple shoot induction and shoots per culture in $R$. serpentina. For multiple shoot induction BAP has played a key role. Atta-Alla and Van (1997) produced an average of 6.6 shoots of Yucca alifolia on MS medium with $4.4,8.9$ or $17.8 \mu \mathrm{m} \mathrm{BA}+2.7 \mu \mathrm{m}$ NAA. The combination of NAA with BAP was effective in shoot bud production (Ghosh and Banerjee, 2003; Ojha and Choudhary,2013). In the present study, the best callusing from the base of explants were recorded on $4 \mathrm{mg} / \mathrm{l}$ BAP and $1 \mathrm{mg} / \mathrm{l}$ NAA.

Elongation of elongated shoots: Of the different tired concentration of NAA and BAP, the best result of shoot elongation and direct shoot regeneration were observed at $0.5 \mathrm{mg} / \mathrm{l}$ BAP with $3.0 \mathrm{mg} / 1$ and $2.0 \mathrm{mg} / 1$ NAA (Plate1a).The shoots attained a length of $4.22 \mathrm{~cm}$

Table 1. In vitro response from shoot apex explants of $W$. somnifera cultured on different compositions of (BAP, NAA) MS media.

\begin{tabular}{|c|c|c|c|c|c|c|}
\hline \multicolumn{2}{|c|}{ Phytohormone in $\mathrm{mg} / \mathrm{l}$} & \multirow{2}{*}{$\begin{array}{c}\text { Response } \\
(\%)\end{array}$} & \multirow{2}{*}{$\begin{array}{l}\text { No.of shoots } \\
(\text { Mean } \pm \text { SD) }\end{array}$} & \multirow{2}{*}{$\begin{array}{l}\text { Average length } \\
\text { shoot in cm } \\
(\text { Mean } \pm \text { SD) }\end{array}$} & \multirow{2}{*}{$\begin{array}{l}\text { Induction of } \\
\text { callus }^{*}\end{array}$} & \multirow{2}{*}{$\begin{array}{l}\text { Nature o } \\
\text { callus }\end{array}$} \\
\hline BAP & NAA & & & & & \\
\hline 0.5 & 0.5 & 73 & $3.28 \pm 0.41$ & $3.34 \pm 0.35$ & + & $\mathrm{S}, \mathrm{F}, \mathrm{W}$ \\
\hline 0.5 & 1.0 & 53 & $4.44 \pm 0.27$ & $3.64 \pm 0.38$ & + & $\mathrm{S}, \mathrm{F}, \mathrm{WB}$ \\
\hline 0.5 & 2.0 & 57 & $3.36 \pm 0.41$ & $4.12 \pm 0.28$ & - & - \\
\hline 0.5 & 3.0 & 55 & $3.26 \pm 0.62$ & $4.22 \pm 0.41$ & - & - \\
\hline 1.0 & 1.0 & 65 & $6.18 \pm 0.36$ & $3.22 \pm 0.78$ & + & $\mathrm{S}, \mathrm{F}, \mathrm{WB}$ \\
\hline 1.0 & 0.5 & 70 & $6.22 \pm 0.31$ & $2.58 \pm 0.20$ & ++ & $\mathrm{S}, \mathrm{F}, \mathrm{WB}$ \\
\hline 2.0 & 0.5 & 68 & $6.50 \pm 0.64$ & $2.60 \pm 0.32$ & +++ & $\mathrm{F}, \mathrm{B}$ \\
\hline 3.0 & 0.5 & 74 & $6.68 \pm 0.51$ & $2.76 \pm 0.42$ & +++ & $\mathrm{F}, \mathrm{WB}$ \\
\hline 4.0 & 0.5 & 75 & $6.80 \pm 0.50$ & $2.98 \pm 0.59$ & ++++ & $\mathrm{S}, \mathrm{F}, \mathrm{WB}$ \\
\hline 4.0 & 1.0 & 85 & $7.56 \pm 0.59$ & $2.28 \pm 0.26$ & +++++ & $\mathrm{F}, \mathrm{W}$ \\
\hline
\end{tabular}

*Visual observation; number of + sign indicates relative amount of callus; - = no response; $\mathrm{W}=\mathrm{white} ; \mathrm{B}=\mathrm{brown} ; \mathrm{F}=\mathrm{friable} ; \mathrm{SF}=$ semifriable. 


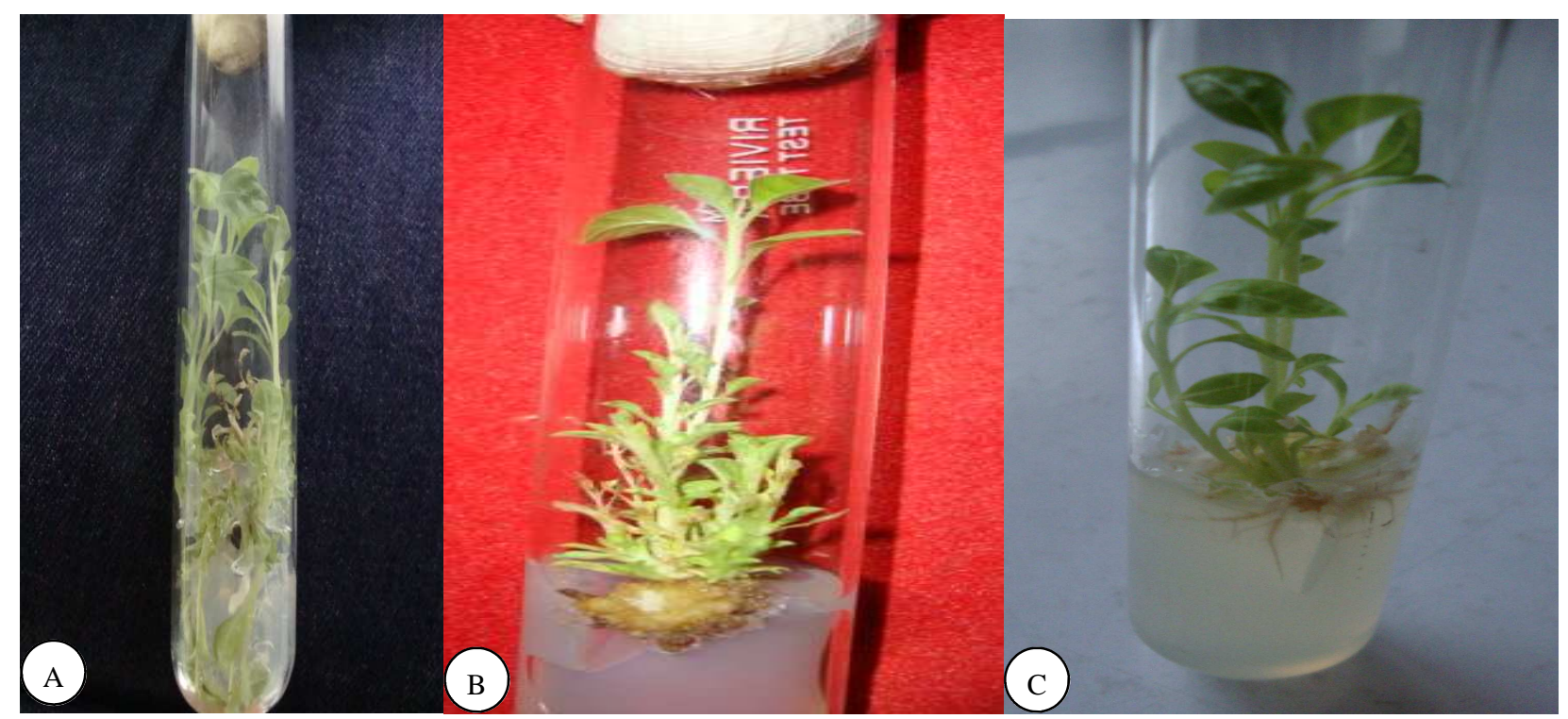

Plate 1. In vitro responses from shoot apex in genotype WA-20 of W. somnifera (a) Initiation of multiple shoots (b) Callus mediated shoot differentiation (c) Rooting of regenerated shoots .

Table 2. In vitro response from shoot apex explants of $W$. somnifera cultured on different compositions of MS media.

\begin{tabular}{|c|c|c|c|c|c|c|c|}
\hline \multicolumn{3}{|c|}{ Phytohormone in mg/l } & \multirow{2}{*}{$\begin{array}{c}\text { Response } \\
(\%)\end{array}$} & \multirow{2}{*}{$\begin{array}{c}\text { No.of root/ } \\
\text { shoots } \\
(\text { Mean } \pm \text { SD) }\end{array}$} & \multirow{2}{*}{$\begin{array}{c}\text { Average length } \\
\text { root in } \mathrm{cm} \\
(\text { Mean } \pm \text { SD) }\end{array}$} & \multirow{2}{*}{$\begin{array}{l}\text { Induction of } \\
\text { callus }\end{array}$} & \multirow{2}{*}{$\begin{array}{c}\text { Nature of } \\
\text { callus }\end{array}$} \\
\hline IBA & IAA & NAA & & & & & \\
\hline 0.5 & & & 89 & $10.06 \pm 0.53$ & $5.07 \pm 0.47$ & - & - \\
\hline 1.0 & & & 78 & $6.66 \pm 1.08$ & $4.49 \pm 1.08$ & - & - \\
\hline 1.5 & & & 78 & $6.23 \pm 0.33$ & $3.72 \pm 0.20$ & - & - \\
\hline 2.0 & & & 63 & $5.12 \pm 0.65$ & $3.40 \pm 0.68$ & - & - \\
\hline 3.0 & & & 39 & $2.25 \pm 0.39$ & $1.08 \pm 0.10$ & - & - \\
\hline 2.0 & 2.0 & & 56 & $1.64 \pm 0.40$ & $1.50 \pm 0.26$ & - & - \\
\hline 4.0 & 2.0 & & 48 & $1.75 \pm 0.14$ & $1.76 \pm 0.23$ & - & - \\
\hline 4.0 & & 2.0 & 68 & $1.69 \pm 0.12$ & $2.00 \pm 0.28$ & +++ & $\mathrm{F}, \mathrm{W}$ \\
\hline 2.0 & & 2.0 & 75 & $2.34 \pm 0.20$ & $1.32 \pm 0.13$ & +++ & $\mathrm{S}, \mathrm{F}, \mathrm{WG}$ \\
\hline
\end{tabular}

*Visual observation; number of + sign indicates relative amount of callus; - = no response; $\mathrm{W}=$ white; $\mathrm{B}=$ brown; $\mathrm{F}=$ friable; $\mathrm{SF}=$ semifriable.

within 25 days of inoculation (Table 1). From this study, it is inferred that $0.5 \mathrm{mg} / 1 \mathrm{BAP}$ with $3.0 \mathrm{mg} / 1$ NAA was the best for the elongation of regenerated shoots from the shoot tip explants. Increasing the concentration of BAP augment the multiplication of shoot buds markedly, but did not affect the elongation of shoots. However, Ghosh and Banerjee (2003) reported that increasing concentration of NAA did not affect the multiplication of shoot bud ,but suppressed the elongation of shoots when shoot apex of Rauvolfia tetraphylla cultured on MS media supplemented with different concentrations of NAA and BAP. Adhikari and Pant (2013) observed the best growth of callus in the MS medium supplemented with $0.5 \mathrm{mgL}^{-1} \mathrm{BAP}+$
$1.5 \mathrm{mgL}^{-1}$ NAA after 8 weeks in stem disc of W. somnifera. In contrast to present study, BAP and IBA were used to induce elongation of multiple shoots in Vigna mungo (Agnihotri et al., 2001) and Momordica charantia (Agrawal and Kamal, 2004).

Rooting and hardening of regenerated shoots: In the present study, auxins were successfully used to produce roots from regenerated shoots. The elongated shoots were excised from the shoot clumps and inoculated on MS medium containing different concentrations IBA $(0.5,1.0,1.5,2.0,3.0)$ individually and in combinations with IAA and NAA with concentrations $(2.0,4.0)$. The root proliferation was observed after 14-18 days of inoculation. Of these 
different concentrations of auxins tried, the maximum percentage $(89 \%)$ of rooting as well as number of root per culture (10.06) with average elongated length of root (5.07) was observed at $0.5 \mathrm{mg} / \mathrm{l} \mathrm{IBA}$ (Plate $1 \mathrm{c}$ ). The roots were long, pale white, robust with root hairs. Pawar et al. (2001) observed rhizogenesis with a frequency of $90 \pm 5$ on MS media containing IAA at $4 \mu \mathrm{M}$ and NAA at $8 \mu \mathrm{M}$ whereas Govindraju et al. (2003), also observed the root induction of the differentiated shoots on the half strength MS media (both liquid and solid) with IBA $(0.5-1.0 \mathrm{mg} / \mathrm{l})$ alone and in combination with IAA $(0.5 \mathrm{mg} / \mathrm{l})$ in W. somnifera. IBA alone was found more suitable for root induction than NAA and IAA (1.64-2.34no.of root/shoot). Similar results were observed in which maximum shoots rooted when cultured on MS medium containing optimal concentration of IBA (Manickam et al., 2000; Rani et al., 2003; Kumar et al., 2011 and Udayakumar et al., 2013). This suggested that the addition of IBA to rooting medium improved rooting efficiency of shoots. IBA used alone in low concentration showed positive results of rooting while in combination with NAA and IAA at high concentration did not show positive results (1-4 roots/ shoot) of rooting.Patel and Krishnamurthy (2013) observed that the regenerated shoots of $W$. somnifera cultured on MS media with $0.4 \mathrm{mg} / \mathrm{l}$ $\mathrm{NAA}+0.4 \mathrm{mg} / \mathrm{l}$ IBA and produced maximum rooting (80-90\%) with 4-5 roots/shoot.

After 30 days of inoculation on rooting medium, the rooted plantlets were removed from the culture tube and washed with distilled water. These in vitro derived plantlets were transferred to plastic pots containing mixture of sand and FYM in 1:1 ratio for 18 days for hardening. A maximum of $68 \%$ of plantlets were hardened successfully. It was concluded from this study that plant regeneration from shoot apex of $W$. somnifera through callus phase offered a great potential in genetic transformation of this important species. The protocol can be exploited for in vitro generating new genetic variability and production of bioactive constituents from the callus.

\section{REFERENCES}

Adhikari, S. R. and Pant, B. (2013). Induction and proliferation of in vitro Mass of Callus of Withania somnifera (L.) Dunal. Research in Plant Sciences, 1(3):58-61.

Agarwal, M. and Kamal, R. (2004). In vitro clonal propagation of Momordica charantia L. Indian J. Biotech., 3:426-430.

Agnihotri, S., Singh, R.R. and Chaturvedi, H.C. (2001). In vitro high frequency regeneration of plantlets of Vigna mungo and their in vitro growth. Indian J. Biotech., 39:916-920.

Asthana, R. and Raina, M.K. (1989). Pharmacology of Withania somnifera (L.)Dun. Indian Drugs, 26:199-205.

Atta-Alla, H., and Van Staden, J. (1997). Micropropagation and establishment of Yucca aloifolia.Plant Cell Tiss Org Cult., 48:209-212.
Ghosh, K.C. and Banerjee, N. (2003). Influence of plant growth regulators on in vitro micropropagation of Rauvolfia tetraphyllia L. Phytomorpholog.,55 (1):11-19.

Govindaraju, B., Rao, SR., Venugopal, RB., Kiran, SG., Kaviraj, CP. and Rao, S. (2003). High frequency plant regeneration in Ashwagandha [Withania somnifera (L.) Dunal].: an important medicinal plant. Plant Cell Biotechnology and Molecular Biology. 4 (1/2): 49-56.

Kanungo, S. and Sahoo, S.L. (2011). Direct organogenesis of Withania somnifera $\mathrm{L}$. from apical bud. International Res. J. Biotech., 2(3): 58-61.

Kavidra, N.T., Neelesh, C.S., Vaibhav, T. and Brahma, D. (2000). Micropropagation of Centella asiatica (L.) a valuable medicinal herb. Plant Cell Tiss. Org. Cult., 62:175-179.

Kumar, O. A., Yothirmayee, G. and Tata, S.S. (2011). Multiple shoot regeneration from nodal explants of Ashwagandha (Withania somnifera (L.) Dunal. Asian j. Exp. Biol. Sci., 2(4):636-640.

Kumar, A. O., Jyothirmayee, G. and Subba, T. S. (2011). In vitro multiple shoot induction from shoot tip explants of Ashwaganda-an important medicinal plant. International Journal of Plant, Animal and Environmental Sciences, 1(3):64-68.

Manickam, V. S., Mathavan, R.E. and Antonisamy, R. (2000). Regeneration of Indian ginseng plantlets from stem callus. Plant Cell, Tissue and Organ Culture, 62 (3): 181-185

Mishra, L.C., Singh, B.B., Dagenais, S. (2000). Scientific basis for the therapeutic use of Withania somnifera (Ashwagandha): A review.Altern. Med. Rev., 5: 334346.

Misra, H.O., Singh, S. and Kumar, S. (1997). AshwagandhaWithania somnifera cultivation in India. Central Institute of Medicinal and Aromatic Plants, Lucknow. Farm Bull., No. 005

Nagesh, K.S. (2008). High frequency multiple shoot induction of Curculigo orchioides Gaertn: shoot tip v/s rhizome disc. Taiwania, 53:242-247.

Offord, C.A. and Tyler, J.L. (2009). In vitro propagation of Pimelea spicata $\mathrm{R}$. Br (Thymelaeaceae), an endangered species of the Sydney region, Australia. Plant. Cell. Tiss. Org. Cult., 98:19-23.

Ojha, A. and Choudhary, R. (2013). Callus development and indirect shoot regeneration From leaves and stem explants of Stevia Rebaudiana bertoni. Journal of Cell and Tissue Research, 13(2): 3755-3759.

Patel, P. and Krishnamurthy, R. (2013). Feasibility studies on in vitro mass-scale propagation of Indian Ashwagandha (Withania somnifera) cultivars for commercial purpose.Journal of Pharmacognosy and Phytochemistry, 2(2):168-174.

Pawar, P., Teli, N. and Bhalsing, S. (2001). Micropropagation and organogenetic studies in Withania somnifera (L.) Dunal. Journal of Plant Biology. 28:217-221.

Panwar, G.S., Attitalla, I. H., Guru, S.K. (2011). An efficient in vitro clonal propagation and estimation of reserpine content in different plant parts of Rauwolfia serpentina. American-Eurasian Journal of Scientific Research, 6 (4):217-222.

Rani, G., Arora, S. and Nagpal, A. (2003). Direct rhizogenesis from in vitro leaves of Withania somnifera (L.) Dunal. Journal of Herbs, Spices and Medicinal Plants, 10 (3): 47-54. 
Supe, U., Dhote, F. and Roymon, M.G. (2006). In vitro Plant Regeneration of Withania somnifera. Plant Tiss. Cult. Biotech, 16:111-115.

Thomas, T.D. and Shankar, S. (2009). Multiple shoots induction and callus regeneration in Sarcostemma brevistigma Wight and Arnott, a rare medicinal plant. Plant
Biotechnol. Rep., 3:67-74.

Udayakumar, R., Choi, C.W., Kim, K.T., Kim, S.C., Kasthurirengan, S., Mariashibu, T.S., Sahaya, R.J. J. and Ganapathi, A. (2013). In vitro plant regeneration from epicotyl explant of Withania somnifera (L.) Dunal. J Medicinal Plants Res., 7(1): 43-52. 